\title{
Exploration on Theory Framework of Business Model Design
}

\author{
Jian-Zhou DAI \\ Planning and Finance Department of Qilu University of Technology,China \\ 809464018@qq.com
}

\begin{abstract}
Keywords: Value stream, Enterprise business model, Framework.
\end{abstract}
\begin{abstract}
The business model is at the heart of strategic design. A good business model design is the important guarantee for the long-term development of enterprises, being an important source of competitive advantage. Proceeding from the realization of customer value, based on value stream analysis, finding business model involves value discovery, value creation, and value realization and so on. Therefore, the corporate business model should be regard as a system process of value discovery, value creation, value protection, value delivery, value realization. Practice has shown that enterprise business model designed around value stream analysis can ensure that profitable model is more unique and advanced with scientific nature, can bring lasting profit for the enterprise.
\end{abstract}

\section{Introduction}

"Profit" is the natural properties of enterprises, being also determined by its intrinsic properties. Business model is such pattern that can bring value to the enterprise, being a plan and a path that ensures enterprises can achieve sustained profitability, guiding the enterprises to realize how to implement value creation and value realization. Meanwhile, with the intensification of competition in the market in recent years, the profitability of enterprises get more and more attention, business models have increasingly become the basis for the survival and development, design and innovation of business model was naturally and greatly concerned, becoming a core of business strategy planning.

Since 90 s of the 20th century, there has been a rapid development of the research about the business model. Current research is mostly descriptive, review and a lack of deep thought, being not really a comprehensive and clear and practical theory framework, having not yet achieved universal recognition, resulting in that the existing business model research can not provide proper guidance for the diagnosis, analysis, reshaping and innovation of business model. From an enterprise perspective, this article explored the nature of the business model and then established a theoretical framework of enterprise business models.

\section{Literature References}

Concept of business model first appeared in 1957, but it caused concern after in 90s of the 20th century. Since then, with the development of information technology, Internet technology has spawned a variety of business model innovation; the traditional business model was facing with unprecedented challenges. How to shape the business model is to gain competitive advantage in enterprise development. In this context, study about business models has been causing concern, many academics explains the business model from different angles. Summary of existing research, it is significant to understand the nature of the business model and take an in-depth analysis of core of business models.

From the research literature on existing business models, research direction about the business model can be roughly divided into three groups; economic class, operational class, strategic class. Business model research of economy class puts focus on how to get the theoretical logic of structural and institutional arrangements, emphasizing the economic source of rent. Study on the operational business model focuses on how to profit by internal processes and structure. Business model of strategy class directs focus on general considerations of the organization's resources and strategic direction. For now, most of the business model research belongs to the operational strategy class.

This article thinks that the definition of the business model should be made from the background and nature of the enterprise. Business model has been able to gain quick development just because that some 
companies by virtue of its unique mode of operation have achieved excellent operating results with strong competitive advantages. At the same time, enterprises, creating and realizing value is the basis for the survival and development enterprises, enterprises that can not create and realize value, can not exist in the market. The book "Reinvent Your Business Before It's Too Late" by Tim Breene and Paul Nunes at Accenture company pointed out that the real evergreen enterprises are all put focus on the promotion of sales and profits. In 1998, the book "The Profit Zone" produced the customer-centric thinking pattern to determine enterprise strategy by such as the basic model of customers choosing, product differentiation (implementation of strategic control) and determination of business scope, as shown in table 1. This book worked out the issue of how to achieve sustained profitability, and made 22 kinds of specific business models. For standard of business model design, the book "How to Design a Winning Business Model" by Ramon Casadesus-Masanell and Joan Ricart put forward three criteria for the evaluation of business model design: firstly, whether the business model is with consist with corporate vision; Secondly, whether the business model is self-reinforcing; thirdly, whether the business model is solid and reliable.

Table 1 Elements of Enterprise Strategy Designed

\begin{tabular}{|c|c|c|}
\hline Elements & Issure to address & Specific content \\
\hline Customer choosing & $\begin{array}{c}\text { To whom we want to } \\
\text { provice with services. }\end{array}$ & $\begin{array}{c}\text { What we can provide those customers with? can I } \\
\text { make money from the customer? I hope to chooe } \\
\text { what kind of customers? }\end{array}$ \\
\hline Value obtaining & $\begin{array}{c}\text { How will we get } \\
\text { profit? }\end{array}$ & $\begin{array}{c}\text { How to create value for customers, thus gaining a } \\
\text { part as my profit? what business model to take? }\end{array}$ \\
\hline $\begin{array}{c}\text { Product } \\
\text { differentiation } \\
\text { /strategic control }\end{array}$ & $\begin{array}{c}\text { How can we protect } \\
\text { profit streams? }\end{array}$ & $\begin{array}{c}\text { Why customer will buy service from me? What is } \\
\text { difference between my value judgements and our } \\
\text { competitors'? what are the features? What kind of } \\
\text { strategic control model can offset competitors' } \\
\text { advantage? }\end{array}$ \\
\hline Area of business & $\begin{array}{c}\text { What business } \\
\text { activities we will be } \\
\text { engaged in? }\end{array}$ & $\begin{array}{c}\text { What products, services and solutions we would } \\
\text { like to provide? what business I want to make? } \\
\text { what role it will play? What business we are going } \\
\text { to subcontract, outsource or make collaborative } \\
\text { production with other companies? }\end{array}$ \\
\hline
\end{tabular}

(From: The Profit Zone, 1998 by mercer management consulting, inc.)

Summarizing existing research literature, this article thinks that the nature of commercial mode is a system structure with a strong logic, which can play a role only as whole; whose core is value creation and implementation; which itself has competition advantage, that is good commercial mode can protection enterprise in market with advantage status; which exists in certain environment, having cyclical and dynamic feature. Thus, ideal theory framework of business model should be able to reflect a comprehensive picture of the enterprise profit, which can explain and clarify existing enterprise business model; which can reflect the structure and components of the business model, can guide enterprises go through innovation and reshaping of business models; which can guide enterprises to make self-diagnosis and found the shortcoming with the help of theoretical framework. If the business model framework in reality can not meet the above requirements, then its value will be compromised. Based on above points, from a business perspective this article tried to build a logical framework of business model, with the core of the value creation and value realization, value analysis as a tool, combination of existing research and practice.

\section{An analysis of business model based on value}

\section{Research Objects and Methods}

The main study objects of this article are for-profit organizations--enterprises, researching enterprises profitable patterns. Its main objective is, through the system analysis of enterprise profit source, to 
establishing a new paradigm for revenue model design to enhance the effectiveness of enterprise revenue model design.

This article took the literature study method to collect, collate, analyze existing research results on enterprise profit model, making an analysis of the value chain theory literature. By real-life case such as Coca-Cola, Tetra Pak and some film companies, it made empirical analysis of a revenue model changes and, finally, through inductive and deductive methods coming up with the general paradigm of enterprise revenue model based on value stream.

\section{Construction of Theory Framework of Business Model Design}

Enterprise's fundamental purpose is to meet customer demand, implementing your own income in the process of. Therefore, the enterprise must first be clear about the value source, through the analysis of the ecological environment, and to choose value proposition. After the value proposition, the enterprise should set business scope around the value position, developing products or services, entering the value creation process. After enterprise complete the corresponding value creation, companies must also select the appropriate channels, passing generated values, laying the foundations for value realization. Meanwhile, enterprises are in a competitive environment, business model must also include the value management, through which enterprises prevent the business model being imitated to gain self-reinforcing of business model. Therefore, the theoretical framework of enterprise business model design is shown in Figure 1:

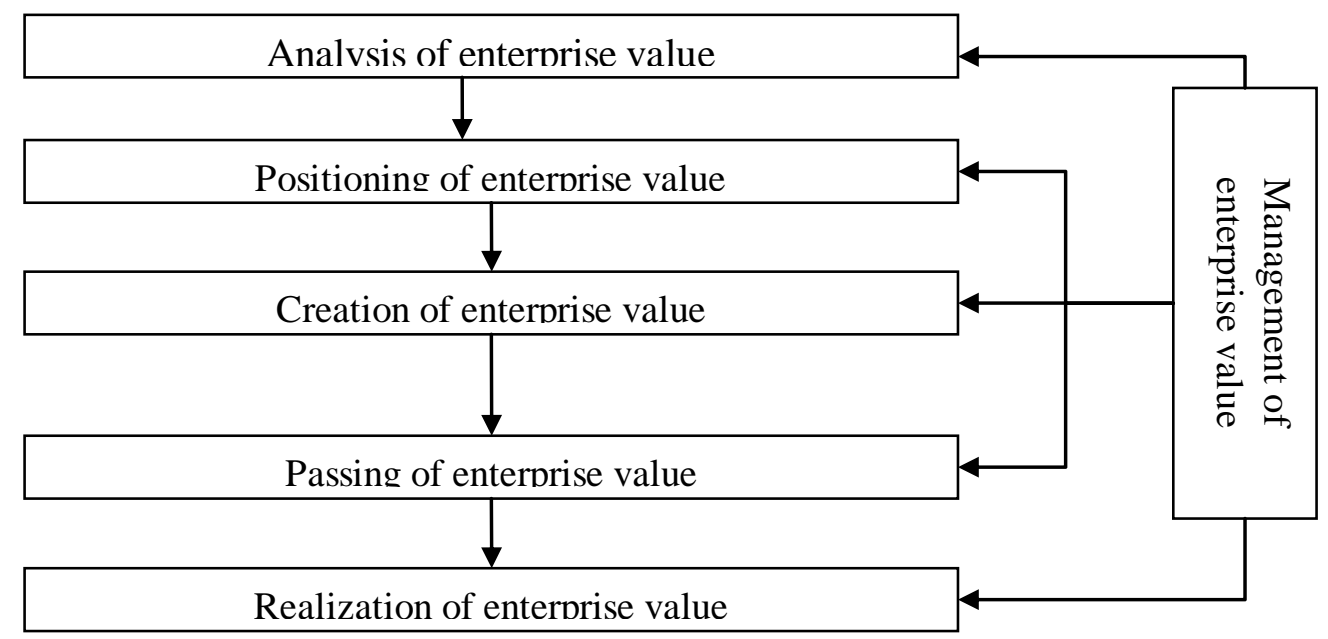

Figure 1 Theoretical frameworks of enterprise business model design

\section{Source of enterprise value}

Enterprise value has many kinds of definition; one view is that enterprise value is equal to the discounted value of expected cash flows, which is basically the same as long-term profits of the enterprise. Another view is that the enterprise value is the sum of net assets and goodwill of enterprise value. This article considers that enterprises are more concerned about profitability, which is the foundation of enterprise value, which comes from the company's future earnings, so this article defines enterprise value as the long-term profitability of enterprises.

Where enterprise value is comes from? This is the first question which business model has to answer, being also the base of business model. An enterprise without an unidentified source of value can not keep a sustainable development and competitive position. The book "the profit zone" makes it clear that corporate profits come from customers, companies must establish a customer-centric thinking. Zhu Yi (2011), pointed out that research of customer value is the foundation of business model research, the fundamental purpose of business model design is creating new value for the customer experience. Therefore, the enterprise value can be further defined as the amount that exceeds the expense paid for cost of serving customer needs. At the same time, we must pay attention to that the scope of modern customers 
has been greatly broadened, which is not limited to organization or individual who make direct purchase of products or services. The scope has been extended to all organizations or individuals associated with the enterprises' interests. Brandenburger and Nalebuff (1996) introduced a value net theories, pointing out that the source of enterprise value is not only the direct consumer but also complementarities which can bring value to the entire network, make an increase of enterprise value sources.

How to analyze the source of enterprise value, this should be the primary content for business model framework, is also a starting point for business models. To make an analysis of enterprise value source, it is necessary to analyze the macro-, meso- and micro-environment, in particular, to establish a customer-centric thinking. Therefore, the business model is an important component of corporate strategy, which is based on the enterprise value chain system. Enterprise, which exists in ecological environment, should make an analysis of resources and capacities within this environment to determine whether this ecological system can support customers' value avocation, then determine the final direction to integrate the ecological system. Therefore, the analysis of the business value source is in fact a complete strategic analysis, decision making process. About the methods of analysis of the business value source we can reference the book "the Profit Zone". This part is to analyze the enterprise value, analyze the distribution of profits on the market, so this section can be defined in terms of value discovering.

\section{Selection of enterprise value}

Through the analysis of enterprise value, we can identify the company's "economic area". Those areas can be divided into average profit area, high profits and low profit and non profit area. Being in different profit areas, there should be completely different business model; its profit is naturally different. For different companies, the selection of profit area depends on the business vision, business capacity and resources, the business model you choose should match the resources, capacities and enterprise. Of course, for any companies, their capacities and resources are dynamic, where the "economy zone" is dynamic, so their business model is necessarily dynamic.

Through the analysis of company's "economic area" and analysis of enterprise internal business, enterprise should make a decision of profit zone into which they are planning to enter, which match specific conditions of enterprises to select customer with whom they want to provide service. This content could be defined as value proposition of business model.

\section{Creation of enterprise value}

After a clear propositioning of enterprise value, it is necessary to set enterprise business services according to the needs of client groups, to develop products or services, organize transformation of production resources, raw materials, into concrete products and services, to realize the potential added value during this process. This process is usually done by enterprise operating systems; efficiency level of enterprise operation directly determines the effect of value creation.

To this end, all aspects of business models are closely linked, accurate positioning of enterprise value and proper selection of profit zone, but with a misconduct of value creation, various aspects of the business model would appear in the "out-of-touch" phenomenon, and eventually established business models can produce proposed value. Therefore, the business model should be carried out throughout all activities; it is meaningless to make a strict differentiate between business models and business strategies.

At present, of more and more customers are involved in activities of value creation, whether for product development or service delivery, customer participation is an important source of value creation. The value of business model is primarily creation of convenient, low cost, novelty, cohesive, locking, user innovation.

\section{Transition of enterprise value}

After the development and production of product or service, enterprise has to choose proper channel to transfer product or service effectively on to consumers. This link includes both enterprise logistics system, also includes enterprise sales channel selection, advertising strategies, and so on. Efficient value delivery system is a good complement of enterprise value and can also effectively reduce resource consumption. Transition process effectively links enterprise value creation and enterprise value realization, being a bridge between the two, being also an important part of enterprise business model design. 


\section{Realization of enterprise value}

Business model takes customer value creation as the starting point, the enterprise value as the ending point, so any business model finally had to boil down to "how to profit," the most fundamental problems. Corporate income mode can be broken down to three sources of income, revenue, revenue way relatively independent function modules, which closely linked and can not function properly without others.

Revenue sources are to solve the issue "where I charge", being a source from which enterprises can obtain the revenue. Value provided to consumers generally includes a lot of content, but often only part of it will charge a fee, these constitute the company's revenue sources. Revenue solves the issue "who enterprise charge", being customer groups from whom enterprise will obtain income. Revenue way is to solve the issue "How to charge". Revenue way is the practical implementation of the revenue model, providing the conditions and rules for the payment customer, ensuring the final implementation of enterprise income.

\section{Manage of enterprise value}

A large number of cases show that if the necessary value management was omitted, effective business models tend to be short-lived, and quickly lose their original purpose. Therefore, the effective business model design must include value management to maintain and manage enterprise value. From the specific content of value management, it can be divided into value preservation and value optimization. Value preservation is a way to prevent foreign interference, which should be designed to contain value proposition, value creation, and value delivery. Value optimization is to mainly complete the strengthening of the business model itself, which is carried out through those steps of value creation, value analysis, value orientation, and delivery by the business model to constantly improve and optimize self-reinforcing of business model.

\section{Conclusion}

The fundamental reason that enterprises can survive is its ability to make profit, but the profit is made by meeting the customer needs and achieved by implementing customer value. Therefore, the theoretical framework of business model design should be customer-centric, should make an analysis of enterprise value sources, and then according to the internal and external environment of enterprises to make value proposition. On this basis, combined with the enterprise value delivery process, the theoretical framework of business model design can be divided into: value analysis, value proposition, value creation and value management, value delivery, value management six parts which are closely linked components, together constituting a rigorous logical system. According to this theoretical framework, enterprise can make business model design, diagnosis, innovation, and so on.

\section{Acknowledgement}

The author would like to express his thanks to the regional innovation and sustainable development research base of Shandong province college humanities and social science research base for the financial support.

\section{References}

[1] Stewart, D W, and Zhao, Q. Internet marketing, business models, and public policy [J] Journal of Public Policy \& Marketing ,2000, 19 (3): 287-296.

[2] Afuah, A, and Tucci, C, Internet business models and st rategies: Text and cases[M]. Boston : McGrawOHill/ Irwin, 2001: 32-33.

[3] Mahadevan, B, Bus iness models for Internet-based e-commerce: An anatomy[J], California Management Review, 2000 , 42(4) : 55-56. 
[4] Amit, R, and C Zott, Value creation in e-business[J], Strategic Management Journal, 2001, 22 (6/7): 493-520.

[5] Osterwalder, A, The business model ontology-A proposition in a design science approach[R], Universitéde Lausanne, 2004.

[6] Rob Smith, Mark Thompson, and Mark Speaker. The complete D DT's guide to e-Commerce [M] , London: Alpha, 2000.

[7] Weill P, and Vitale M R. Place to s pace: Migrating t o eBusiness Models [M]. MA: Harvard Business School Press, 2001.

[8] Dubosson-Torbay M, Osterwalder A, and Pigneur Y. E-Business model design, classification and measurements[J]. Thunderbird Interna2ti onal Business Review, 2002, 44 (1): 5-23.

[9] Linder J. \& Cantrell S. Changing business models: Surveying the landscape R. Accenture Institute for Strategic Change 2000.

[10] Pateli A. and Giaglis G.M. A Framework For Understanding and Analysing e-Business Models. Proceedings of the Bled Electronic Commerce Conference. 2003.

[11] Osterwalder A. Pigneur Y. An e -Business On tology for Modeling eBusiness R. 15th Bled Electronic Commerce Conference Bled Slovenia. 2002. 